\title{
The planning and orientation of the Dolmens of Rego da Murta (Alvaiázere, Portugal)
}

\author{
Alexandra Figueiredo ${ }^{1}$, Benito Vilas-Estévez ${ }^{2}$ and Fabio Silva ${ }^{3,4, *}$ \\ 1 - Unidade Departamental de Arqueologia, Conservação e Restauro e Património, \\ Instituto Politécnico de Tomar, Tomar, Portugal and Centro de Investigação \\ Geociências, Portugal. \\ ${ }^{2}$ - Departamente de Historia, Arte e Xeografia, University of Vigo \\ 3 - Faculty of the Humanities \& Performing Arts, University of Wales Trinity Saint \\ David, Lampeter Campus, Ceredigion SA48 7ED, United Kingdom \\ 4 - IPHES, Institut Català de Paleoecologia Humana i Evolució Social, Tarragona, \\ Spain and Àrea de Prehistòria, Universitat Rovira i Virgili (URV), Zona Educacional, 4 \\ - Campus Sescelades URV (Edifici W3), 43007 Tarragona, Spain \\ * corresponding author: f.silva@uwtsd.ac.uk
}

\begin{abstract}
During the excavation of Dolmen I of Rego da Murta, a structure belonging to a megalithic cluster in central Portugal, a number of small sub-quadrangular quartzite stones were found embedded within a layer that is below that of the deepest orthostat. In this paper, we report on these findings and highlight three key features of these small stones, namely their location relative to the dolmen's plan, the distances between them and their orientations. We suggest the quartzite stones could have been markers used in the planning of construction of this megalithic structure. In addition, we also measured and analyse the orientation of the two main structures of the cluster (Dolmen I and Dolmen II), also captured by the quartzite stones, and suggest potential landscape and skyscape alignments for them, including three hypotheses for the observed differences in orientation between the two.
\end{abstract}

In this paper, we focus on recent work done in the megalithic cluster of Rego da Murta, in central Portugal, where two dolmens, or antas in the original Portuguese, have been intensively excavated. The finding of a number of small quartzite stones embedded within the deepest layer, their location with respect to the placement of the orthostats, and the orientations they form between themselves, are indicative of their use in planning the construction of one of the monuments. We therefore report on this discovery and do a preliminary assessment of this possibility.

In addition, it was observed that some of the orientations they mark out is reflected in the orientation of the passage, or corridor. This adds weight to the hypothesis that the orientation of these structures was intentionally considered and, hence, an analysis of the orientation of these two structures is also done, in particular, with respect to potential alignments with orographic and/or celestial features. With only two monuments fully excavated, a statistical analysis of orientation as commonly practiced in archaeoastronomy is impossible (e.g. Hoskin 2001, Ruggles 1999). However, we opt for a more in-depth, almost micro-scale approach, looking at each monument in turn and 
Accepted version of article published in Proceedings of Prehistoric Society 84 (2018): 207-224. DOI: 10.1017/ppr.2018.4

listing all the possibilities, before turning to a meso-scale approach in search of similarities and differences at the cluster scale, covering both monuments and taking the wider archaeological record into account, as suggested by Silva (2014).

\section{The Megalithic Cluster of Rego da Murta}

The megalithic cluster of Rego da Murta is a large complex of megalithic monuments located in Alvaiázere, in the district of Leiria, at the center of Portugal (Velho 2003; Figueiredo 2004a; 2013a). The cluster, which extends over an area of about $1 \mathrm{~km}^{2}$, is located on Mesozoic limestone terrains, which form the whole mountain range of Alto Nabão, in the plain between the Zêzere and Nabão rivers, the former a tributary of the Tagus river (figure 1). This region of central Portugal, almost equidistant to the earlier megalithic centres of innovation of the north of Portugal (e.g. Cruz 1995) and of Alentejo, in the south (e.g. Rocha 2010), was the setting of diverse cultural influences (Figueiredo $2006 ; 2007 ; 2010)$. This is demonstrated, for example, by the presence, in the depositional assemblages, of materials collected at larges distances from the cluster, such as chrysoprase beads (Figueiredo 2006), as well as the high percentage of individuals that do not originate from the region (Watterman et al. 2013). It is highly likely that these communities used the Tagus and its tributaries for movement to and from the north and the interior of the country.

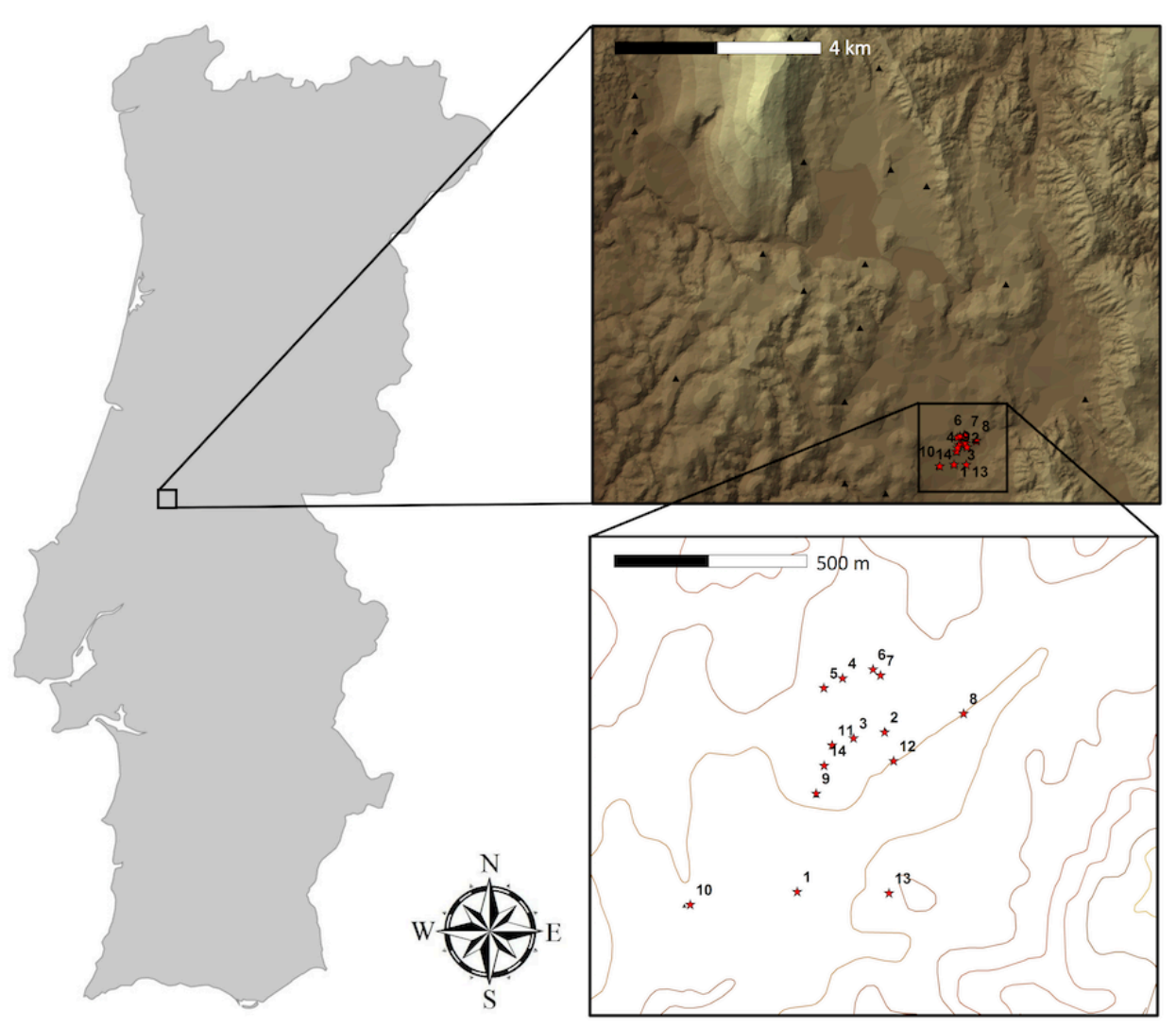

Figure 1 - The megalithic cluster of Rego da Murta, its location and distribution of monuments. Red stars represent the structures of the megalithic cluster as follows: 1 - Dolmen I, 2 - Dolmen II, 3-9 Menhirs, 10-14 - Other structures. Black triangles represent prehistoric structures in the wider region. 
Accepted version of article published in Proceedings of Prehistoric Society 84 (2018): 207-224. DOI: 10.1017/ppr.2018.4

Much like in its neighbouring regions to the north and south, Neolithic and Chalcolithic occupation is mostly visible from funerary depositions in caves, as well as the monumental constructions and associated depositions. Such megalithic structures often appear as part of clusters of monuments, which can also include other atypical structures, that do not fall under the usual morphological types typical of the country - such as dolmen, menhir or cyst. In a few cases, such atypical structures also include funerary deposits, as is the case of Jogada 5 (Cruz 2002) and Colos (Baptista 2006; 2013; Cruz et al. 2016), both located in Abrantes, just south of Rego da Murta.

The megalithic cluster of Rego da Murta has been undergoing excavation since 1998 and, at this moment, integrates a total of fourteen structures - including dolmens, menhirs and other atypical monuments - four of which have been excavated and restored (Velho 2006; Figueiredo 2004b; 2005; 2006; 2007, 2010; 2013b).

The Dolmen I of Rego da Murta is composed of an octagonal chamber and a relatively prominent corridor (figure 2) with more or less the same length as the diameter of the chamber. The excavation works have revealed burials in two distinct periods - the Late Neolithic and the Early Bronze Age - in a long diachrony spanning almost fifteen hundred years (Figueiredo 2006, 77-93). The burials comprise a minimum of fifty-two individuals, of both sexes and different ages, that were associated with wild and domestic animal bones as well as a varied artefactual assemblage. The latter consisted of a wide assortment of ceramic vessels, mostly undecorated; blades and lamellae; some arrowheads, mostly with triangular base; a large set of necklace beads, mostly in slate; and polished objects (axes and gouge). In addition to the burials, a large circular structure was identified in the center of the chamber (figure 2), as well as possible traces of paintings on the backstones and a zig zag engraving on an orthostat on the left side (Figueiredo 2006, 38-42).

\begin{tabular}{|c|c|c|c|c|c|c|c|c|c|}
\hline bl & $\mathrm{cl}$ & dl & el & $\mathrm{fl}$ & gl & hl & il & از & $\mathrm{kl}$ \\
\hline bll & cll & dll & ell & fll & gll & hll & ill & jll & kII \\
\hline bIII & clll & & & & & & illI & jIII & kIII \\
\hline blV & cIV & & & iv & & & ilV & jlV & kIV \\
\hline bV & & $\mathrm{dV}$ & & $\mathrm{fV}$ & gV & & iv & jV & $\mathrm{kV}$ \\
\hline $\mathrm{b} \mathrm{VI}$ & $c \mathrm{VI}$ & & & & & & & jVI & $\mathrm{kVI}$ \\
\hline bVII & cVII & & & & & & & JVII & kVII \\
\hline bVIII & cVIII & dVIII & eVII & fVIII & & & & VAll & KVIII \\
\hline bIX & $\mathrm{clX}$ & $\mathrm{dl} X$ & elX & $f \mid X$ & $g \mid X$ & $h \mid x$ & & $\mathrm{jlX}$ & kIX \\
\hline$b x$ & $c x$ & $\mathrm{dX}$ & ex & $f x$ & $g x$ & $h x$ & ix & $j \mathrm{X}$ & $\mathrm{kX}$ \\
\hline & 0 & 1,5 & & eter & & & & & \\
\hline
\end{tabular}

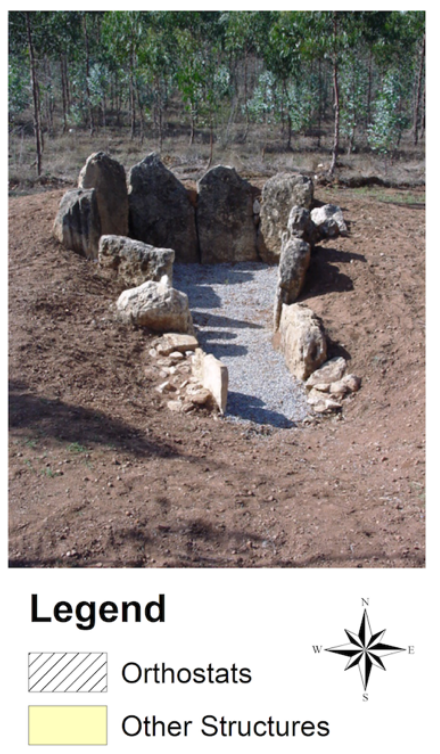

ArcGIS 9.22015

Alexandra Figueiredo

Data from field work 1999-2003

1 meter squares

Figure 2 - Plan of Dolmen I of Rego da Murta (left). Photograph of the dolmen after the restauration works of 2004 (top right). 
Accepted version of article published in Proceedings of Prehistoric Society 84 (2018): 207-224. DOI: 10.1017/ppr.2018.4

Towards the north of this structure is located a second dolmen, the Dolmen II of Rego da Murta, which has also been excavated (Figueiredo 2004b; 2007; 2010). This dolmen differs morphologically from the first one due to the lack of clear distinction between its chamber and corridor - therefore being more of an allée couverte-type structure (figure 3 ). Its archaeological record presents pit deposits closed-off by limestone rocks, and associated with overturned vessels, some of them whole, as well as a multitude of traces that fit chronologically in the mid to late Chalcolithic period. The chamber of this dolmen includes a paved area, probably built in the early to mid Chalcolithic, on top of a series of contemporary or earlier depositions, where small traces of very fractured osteological splinters were identified and one of which was dated (Beta-451546, see below).

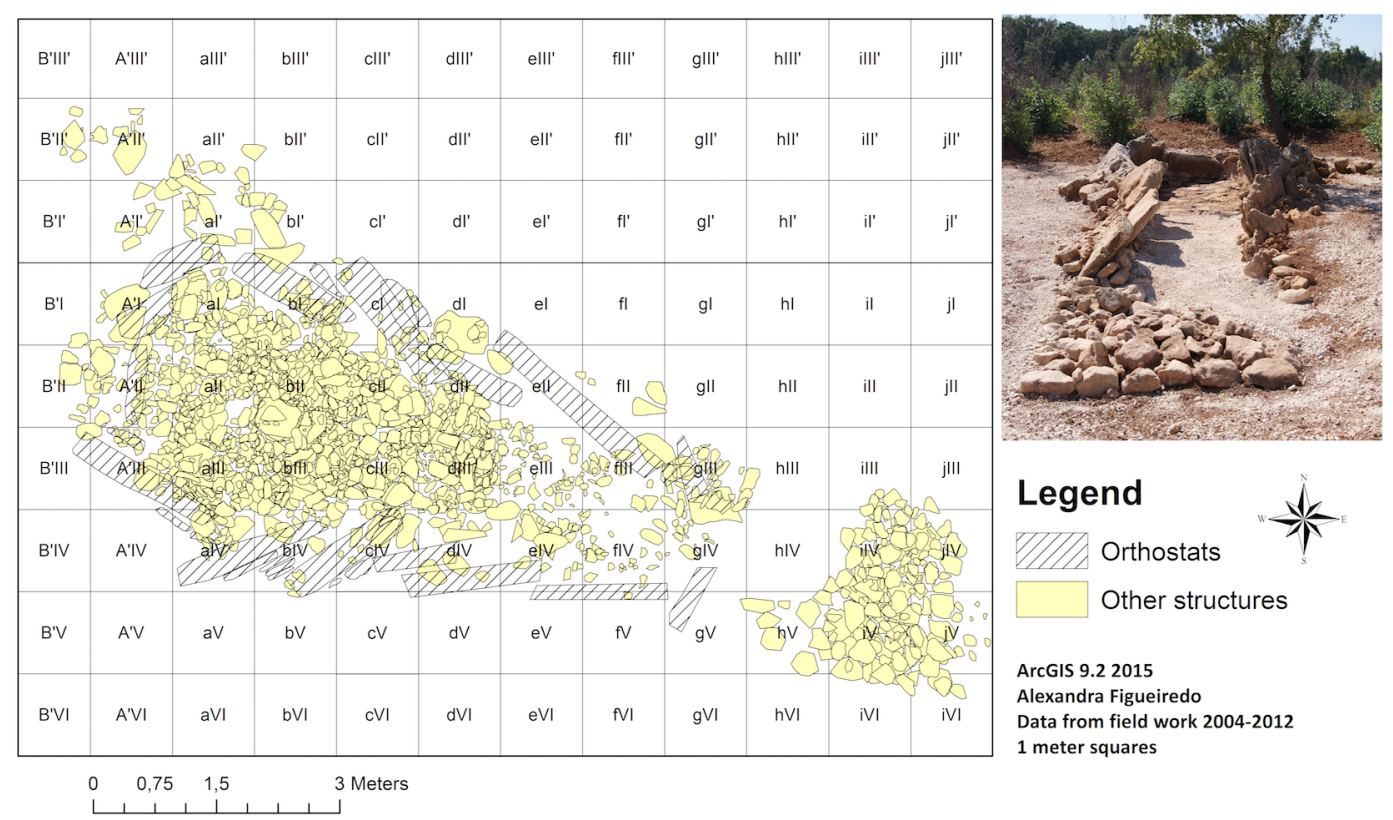

Figure 3 - Plan of Dolmen II of Rego da Murta (left). Photograph of the dolmen after the restauration works of 2012 (top right).

In addition to these two dolmens, two of the menhirs of this cluster have also been excavated (Figueiredo 2013b). Morphologically, they are rounded on one side (the "belly") and flat on the other. In both cases the belly side is facing the north. In Menhir I, a cup mark at the centre of the belly was found. A small deposition consisting of a great number of seeds (unidentified), silex materials and a small ceramic fragment was found near menhir II.

\section{Radiocarbon Dates}

Collagen samples from recovered bone allowed for seven AMS radiocarbon dates from Dolmens I and II (Figueiredo 2010). Together with two more recent dates, both from Dolmen II, they allow a clearer picture of the timing of the use of this cluster to emerge. Table 1 and figure 4 show all the dates obtained, calibrated using the INTCAL13 calibration curve (Reimer et al. 2013), OxCal v4.2 (http://c14.arch.ox.ac.uk/). 
Accepted version of article published in Proceedings of Prehistoric Society 84 (2018): 207-224. DOI: 10.1017/ppr.2018.4

\begin{tabular}{|c|c|c|c|}
\hline Structure & Lab Code & Uncal BP & Cal BC (95\%) \\
\hline \multirow{4}{*}{ Dolmen I } & Beta-190001 & $4520 \pm 40$ & $3370-3090$ \\
\cline { 2 - 4 } & Beta-189998 & $4490 \pm 60$ & $3370-2940$ \\
\cline { 2 - 4 } & Beta-190003 & $4400 \pm 40$ & $3330-2900$ \\
\cline { 2 - 4 } & Beta-190002 & $4370 \pm 40$ & $3100-2900$ \\
\cline { 2 - 4 } & Beta-190000 & $3640 \pm 40$ & $2140-1900$ \\
\cline { 2 - 4 } & Beta-189999 & $3510 \pm 40$ & $1950-1700$ \\
\hline \multirow{5}{*}{ Dolmen II } & Beta-451546 & $4540 \pm 30$ & $3370-3100$ \\
\cline { 2 - 4 } & Beta-190004 & $4290 \pm 40$ & $3330-2770$ \\
\cline { 2 - 4 } & Beta-190007 & $4190 \pm 40$ & $2900-2630$ \\
\cline { 2 - 4 } & Beta-453400 & $4070 \pm 30$ & $2860-2490$ \\
\cline { 2 - 4 } & Beta-190008 & $4060 \pm 50$ & $2870-2470$ \\
\hline
\end{tabular}

Table 1 - Table of absolute AMS dating of bone fragments for both dolmens of Rego da Murta.

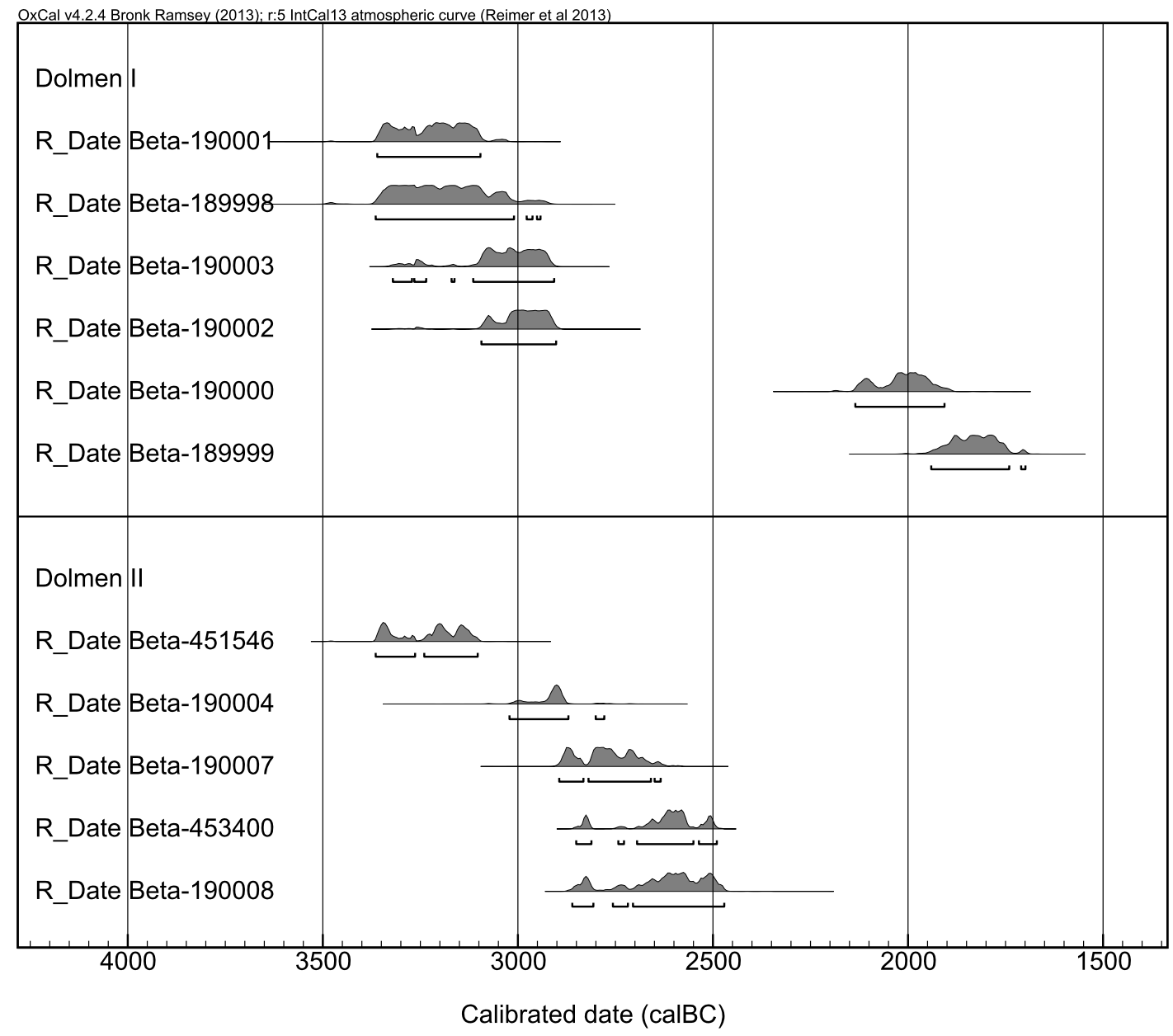

Figure 4 - Probability distributions of dates from the Rego da Murta megalithic cluster. 
Accepted version of article published in Proceedings of Prehistoric Society 84 (2018): 207-224. DOI: 10.1017/ppr.2018.4

Dolmen I presents a first phase, possibly related to its construction and certainly to its first depositions, which corresponds to the Late Neolithic / Early Chalcolithic. This phase is equally represented by one of the dates for Dolmen II (Beta-451546), obtained from one small bone fragment found beneath the pavement of this dolmen. There is then a gap in the diachrony of Dolmen I that is, however, represented by the other dates from Dolmen II. This coincides with a shift in funerary practices which also involved some structural changes of Dolmen II (see next section). A later phase, corresponding to the Late Chalcolithic / Early Bronze Age is then present in Dolmen I only.

\section{Funerary Practices}

As inferred from the archaeological record of these two dolmens, funerary practices were very similar to those inferred from contemporaneous depositions in caves, such as Gruta dos Ossos and Gruta do Cadaval (Figueiredo 2006; 2010). From the latter, it has already been established that, across the period of interest to us, there were two distinct funerary practices. One, prevalent throughout the Neolithic, would have consisted in ritual inhumation and subsequent cult of individuals buried in dolmens and/or caves. Another, which would have started in the mid Chalcolithic, focused on the construction of pits where disarticulated bones from different individuals, irrespective of age and gender, were placed and covered by semi-circular lithic structures which were mixed with other materials, such as pottery, possibly as votive offerings - not unlike ossuaries.

With respect to the dolmens, it is clear that they underwent periods of use and disuse, with profound alterations of the internal structures, albeit with minimal changes to the lithic skeleton (Figueiredo 2006). Both dolmens were likely constructed and used the same time (as indicated by the oldest dates of the two structures, figure 4), most likely under the first of the two funerary practices just mentioned. In the Late Neolithic/Early Chalcolithic the interior of Dolmen II was cleared of its contents, a pavement placed and the ossuaries deposited. It was also at this time that the ceiling of the monument would have been removed, the depositions having been placed directly from above.

Dolmen I was never cleared but its interior presented evidence of having been heavily revolved and the bone assemblages mixed. This might indicate another shift in funerary practice that would have occurred in the Early Bronze Age, in which period burials lack the lithic structures that were visible in the mid-to-late Chalcolithic. In addition, the left side of the corridor of Dolmen I would have been modified in the Early Chalcolithic, when an orthostat would have fallen, as evidenced by depositions found both beneath (with associated AMS date Beta-189998) and above it.

\section{The quartzite Stones}

At the end of the excavation works of Dolmen I, at the bottom of all the archaeological layers, a set of small sub-quadrangular stones were found (figure 5). These, made of quartzite and with regular dimensions - between 10 to $15 \mathrm{~cm}$ of width - were almost equidistant from each other (figure 6). They are very different in shape and in material constitution from other stones used in these monuments. All the megalithic orthostats, as well as the stones used to close-off depositions and buttress the orthostats, are in limestone. Spatially, the quartzite stones occupy the entire extension of the monument, with one of them (A) located between the two backstones, another one (C) in the southern edge of the chamber and yet another $(\mathrm{F})$ at the end of the corridor. 
Accepted version of article published in Proceedings of Prehistoric Society 84 (2018): 207-224. DOI: 10.1017/ppr.2018.4

Figure 5 - Three of the discovered quartzite stone markers in situ.

According to the interpretation of the layers of the Dolmen I of the Rego da Murta (Figueiredo 2006), these stone markers were introduced in the C4 layer, but extended in height to the $\mathrm{C} 3$ layer, which is the level where the orthostats are planted. The top of two stones markers were at the height of the deepest orthostat (the backstone). The archaeological remains of ritual deposition mentioned above were only recorded in the C2 layer. This intentional placement of these stone markers in the ancient soil is suggestive of the existence of a plan for the construction of the monument, prior to the placement of the megaliths forming the chamber and corridor.

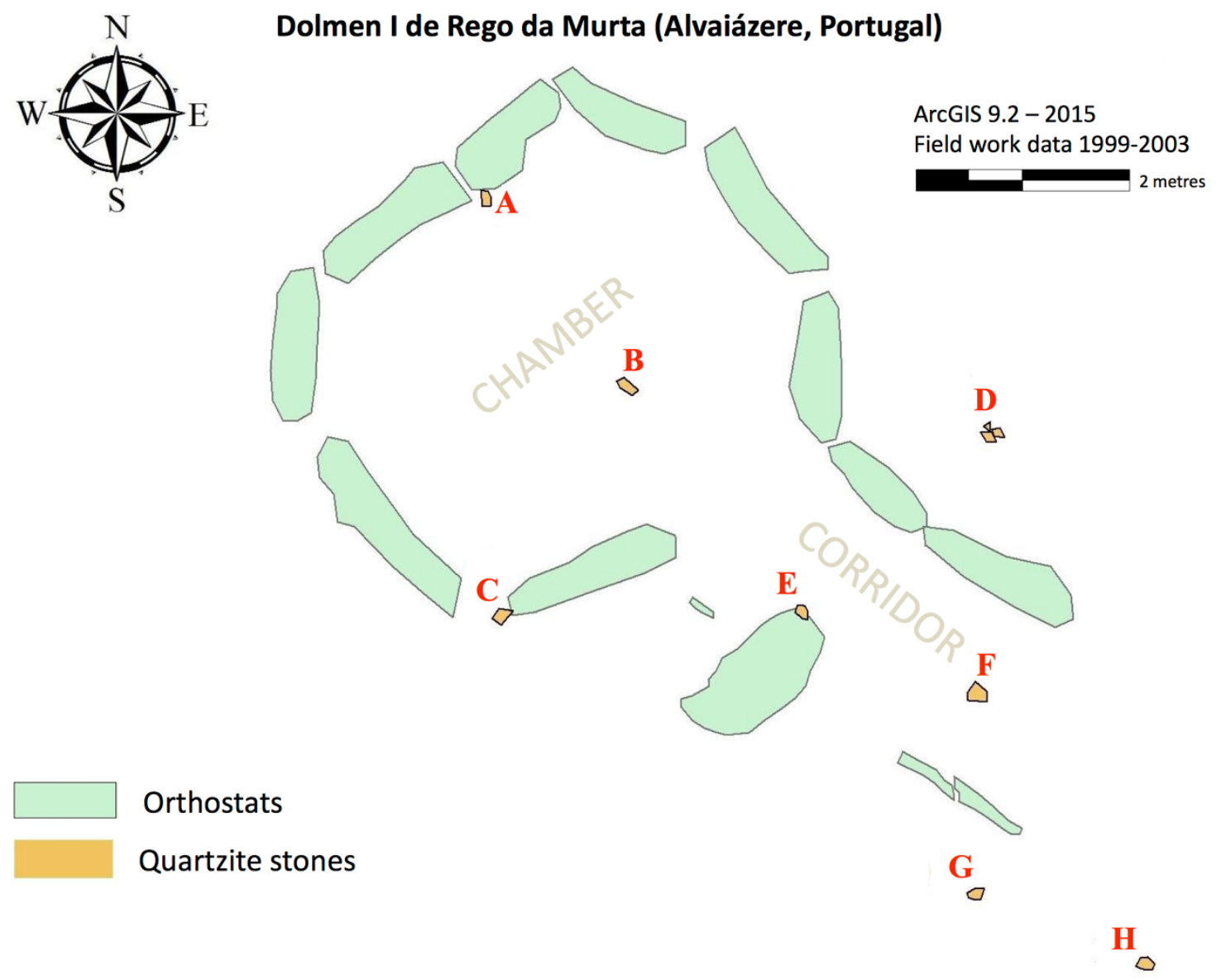

Figure 6 - Plan of Dolmen I, showing the location of the discovered quartzite stone markers.

In Dolmen II, because of the good architectural preservation, the research team did not excavate below the base level of the orthostats, as was done in Dolmen I. However, since a sub-quadrangular quartzite stone was also located near the backstone of this dolmen, we believe that others might be present, mimicking the findings of Dolmen I.

\section{Methodology}

Accurately determining the orientation of a dolmen is not an easy task. Traditionally, archaeoastronomers have measured a supposed axis of symmetry, understood as the direction from the centre of the backstone to the centre of the entrance or passage (Hoskin 
Accepted version of article published in Proceedings of Prehistoric Society 84 (2018): 207-224. DOI: 10.1017/ppr.2018.4

2001). When the entrance had been destroyed, Hoskin states that the direction faced by the backstone will give a reasonable direction and should be used instead.

The problem, as stated by Silva (2014), is that even when a long corridor has survived intact or been accurately restored, the determination of its orientation is plagued by uncertainties. The inherent non-uniformity of the used orthostats, as well as irregularities in their laying, might mean that their builders either were limited by technology, or that a perfect alignment of the corridor stones simply wasn't important to them. In either case, it means that dolmens are rarely symmetric, and that therefore any measurement of a central axis is merely an approximation with unknown uncertainty. As an example, Silva $(2014,26)$ shows that several different, but possible, definitions for a central axis can be measured, and that their orientations can vary by as much as ten degrees.

For these reasons the measurement of the complete range of orientations allowed by the structure's architecture, the so-called window of visibility, has been proposed (Silva 2014). For structures with a passage or corridor, this is given by the diagonals of the passage and the chamber's entrance, yielding minimum and maximum azimuths that correspond to the uncertainty in the measurement of orientation. This is safer as, without projecting modern western notions of axis or symmetry into the prehistoric past, one can say that, if the builders had any intention behind the orientation of the dolmen, then the intended target (celestial, orographic or both) is sure to be within the range given by the minimum and maximum of the window of visibility.

Measurement of the orientation using both the traditional and the window approaches were taken using a survey-grace sighting compass with an advertised precision of $0.5^{\circ}$. These values were corrected for true north using the International Geomagnetic Reference Field model provided by the National Oceanic and Atmospheric Administration website (https://www.ngdc.noaa.gov/geomag-web/?model=igrf\#igrfwmm).

The quartzite stones were removed after excavation, so the orientation between pairs of these stones could not be measured in situ. However, their location was accurately recorded using a total station and, therefore, all reported orientations between two or three quartzite stones were obtained using the COGO module of ArcMap v10.3 (http://desktop.arcgis.com/en/arcmap). To confirm that the azimuth measured in situ and those measured via GIS were comparable we have used the same GIS approach to measure the orientations measured in the field and compare with the magnetic compass readings. We found good agreement between them, to within $0.5^{\circ}$, and therefore we present all results rounded to the nearest half degree.

When interested in potential alignments to celestial objects the azimuth tells only half the story: the altitude of the horizon is equally important, since for a high horizon, a celestial object will be seen to rise at a higher azimuth. It is therefore quite common to measure both azimuth and horizon altitude in the field and, subsequently, calculate the corresponding declination (e.g. Ruggles 1999). In astronomy, declination is the angular distance between a heavenly body and the celestial equator, measured on a great circle that passes through the celestial pole and the heavenly body. It is, therefore, the equivalent of latitude on the celestial sphere. It is useful in archaeoastronomy for the identification of potential targets for alignments.

Due to vegetation cover it was impossible to measure the horizon in situ. It has recently become common to rely on digital elevation models to provide an estimate of the horizon altitude (e.g. Silva 2014). We used the estimates provided by the free software HeyWhatsThat that uses the Shuttle Radar Topography Mission digital elevation model to recreate $360^{\circ}$ horizon panoramas (Kosowsky 2013). This horizon data was then imported into purpose-built $\mathrm{R}$ v3.3.2 code that, together with packages astrolibR and 
Accepted version of article published in Proceedings of Prehistoric Society 84 (2018): 207-224. DOI: 10.1017/ppr.2018.4

palinsol, allows for the quick representation of the orbits of celestial objects at any given time period (R Core Team 2016; Chakraborty et al. 2004; Crucifix 2016). Further work, of an exploratory nature, was done in Stellarium v0.15.1 (http://www.stellarium.org).

\section{Results and Discussion}

The quartzite stones

Our first observation was that stone pairs E-F and G-H are relatively equidistant, $1.60 \mathrm{~m}$ apart (Figueiredo 2006). This distance is exactly what we consider to be the width of the corridor as well as being half the diameter of the chamber and half the length of the corridor (figure 7). These observations suggest a possible standard unit of measurement or the use of an instrument (possibly made from a perishable material such as wood) for the purpose of placing the stone markers and laying out the megalithic structure.

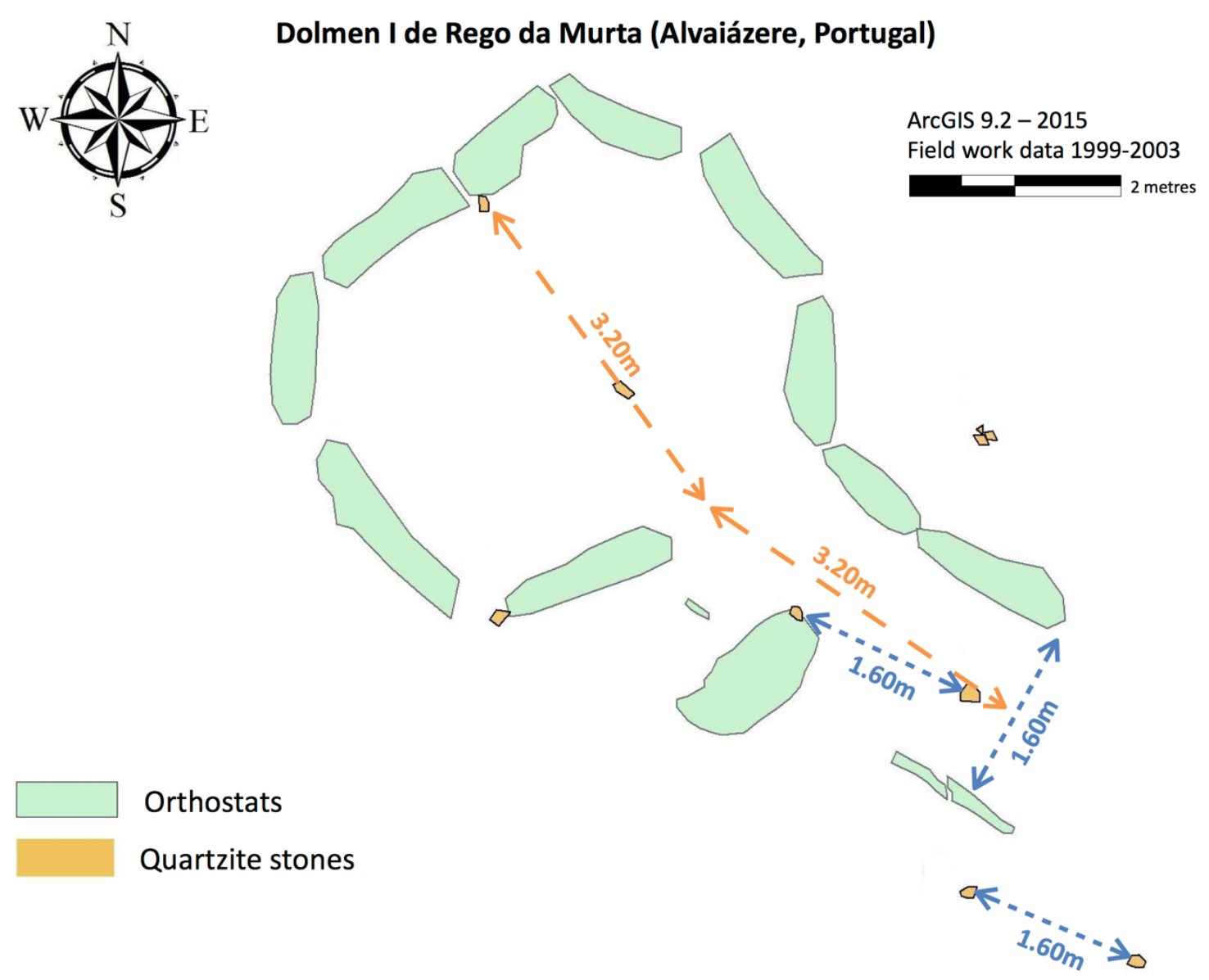

Figure 7 - Key lengths and widths of the dolmen's chamber and corridor, as well as between stone pairs E-F and G-H

It is interesting to note that the smallest length identified $-1.60 \mathrm{~m}-$ is close to the length of two Megalithic Yards (1.66m), the unit of measurement claimed by Alexander Thom to have been used in the construction of British megalithic structures (Thom 1962). However, the significance of the notion of the Megalithic Yard has more recently been downplayed as the available data was also consistent with, for example, the "monuments 
Accepted version of article published in Proceedings of Prehistoric Society 84 (2018): 207-224. DOI: 10.1017/ppr.2018.4

being set out by pacing, with the 'unit' reflecting an average length of pace' (Ruggles 1999, pp. 83), itself a likely interpretation for the lengths identified by us here.

With respect to the orientations provide by combinations of these small stones, table 2 includes the most meaningful ones. Out of the 28 possible combinations of two stones, we include seven which are close to other orientations of interest. To these, we add one combination of three stones (out of 56 possible combinations). Such a selection of combinations is an exercise in subjectivity: we have highlighted above only those orientations that are formed by stones located in what appear to be key architectural locations such as the midpoint of the backstone (stone A), the midpoint of the chamber (stone B) and the entrance of the corridor (stone F). In addition, we have highlighted combinations that are be repeated twice by different stone pairs.

\begin{tabular}{|c|c|c|c|}
\hline $\begin{array}{c}\text { Stone } \\
\text { Combinations }\end{array}$ & Azimuth & $\begin{array}{c}\text { Horizon } \\
\text { Altitude }\end{array}$ & Declination \\
\hline A-F & $134.5^{\circ}$ & $2.5^{\circ}$ & $-30.9^{\circ}$ \\
\hline B-F & $132^{\circ}$ & $3^{\circ}$ & $-28.9^{\circ}$ \\
\hline E-F & $117^{\circ}$ & $5^{\circ}$ & $-17.1^{\circ}$ \\
\hline G-H & $115.5^{\circ}$ & $5^{\circ}$ & $-16^{\circ}$ \\
\hline B-D & $96.5^{\circ}$ & $5^{\circ}$ & $-1.8^{\circ}$ \\
\hline C-F & $98.5^{\circ}$ & $5^{\circ}$ & $-3.8^{\circ}$ \\
\hline A-C & $179^{\circ}$ & $1.5^{\circ}$ & $-49.1^{\circ}$ \\
\hline D-F-G & $181^{\circ}$ & $1.5^{\circ}$ & $-49.1^{\circ}$ \\
\hline
\end{tabular}

Table 2 - Orientation of the quartzite stone combinations, including their azimuth, altitude of the horizon along that azimuth and corresponding celestial declination.

Some of these, such as combinations A-F and B-F, are within a couple of degrees, of the orientation of the corridor of the structure. Others $(\mathrm{E}-\mathrm{F}$ and $\mathrm{G}-\mathrm{H})$ match the orientation of a conspicuous hilltop on the horizon. Both of these will be discussed in more detail below. Other combinations might have served as indicators of the cardinal directions. Stone combinations A-B and D-F-G, indicate North-South directions with a pretty good accuracy, whereas stone pairs B-D and C-F are pointing seven to nine degrees south of a true East-West direction.

Their location with respect to the structures identified, as well as the fact that some of these produce orientations very close to the traditional archaeoastronomical measurement of orientation, does suggest that the quartzite stones may have been used in planning the construction of the monument, which would have included the marking of its orientation prior to construction. How this would have occurred, and what was the role of the stones paced outside of the megalithic structure (namely, stones D, G and $\mathrm{H}$ ) we do not know. Nevertheless, we hope that, with future research and possible new finds in the other structures of the megalithic cluster and elsewhere, we can test and further refine this working hypothesis. 
Accepted version of article published in Proceedings of Prehistoric Society 84 (2018): 207-224. DOI: 10.1017/ppr.2018.4

The traditional axis of symmetry of Dolmen I (the dotted arrow of figure 8) shows a declination of $-30.6^{\circ}$, which is very close to the orientations given by stone pairs A-F and $\mathrm{C}-\mathrm{F}$, as mentioned above. In terms of landscape this orientation doesn't match any particularly interesting orographic feature (see the dotted line in the reconstructed horizon of figure 8). On the other hand, in terms of skyscape, this orientation is outside the range of sunrise which, for the period under consideration, occurs between declinations $+24^{\circ}$ and $-24^{\circ}$. The moon, however, can rise at such an extreme position on what is know as a major standstill year - which occurs once or twice every 18.6 years. Moonrise on such an extreme position, one which the sun never reaches, is well established for many cultures (e.g. Malville 2015) and its unique features when associated with the solstices provide other possible reasons for considering it a potential target of an alignment (e.g. Sims 2016). An alternative suggestion, however, is the constellation of the Southern Cross which, during the Late Neolithic, would have its top-most star, Gacrux, rise in this horizon point.

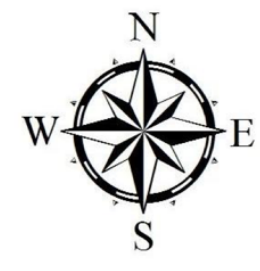

\section{Dolmen I de Rego da Murta (Alvaiázere, Portugal)}
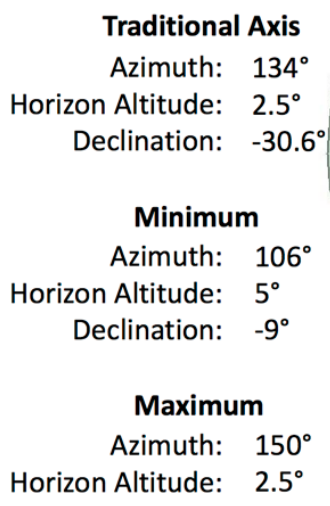

Horizon Altitude: $2.5^{\circ}$

Declination: $\quad-39.9^{\circ}$
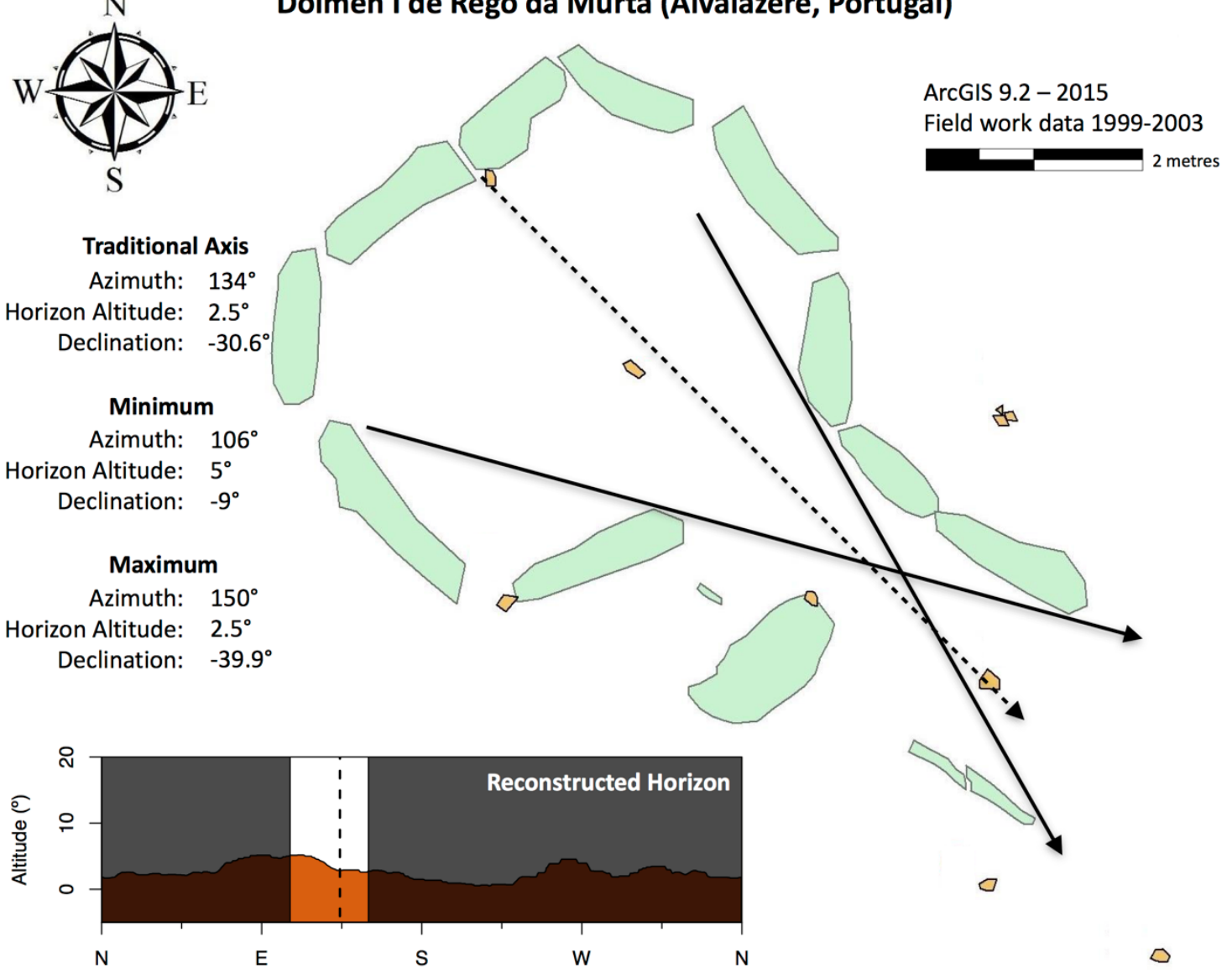

品

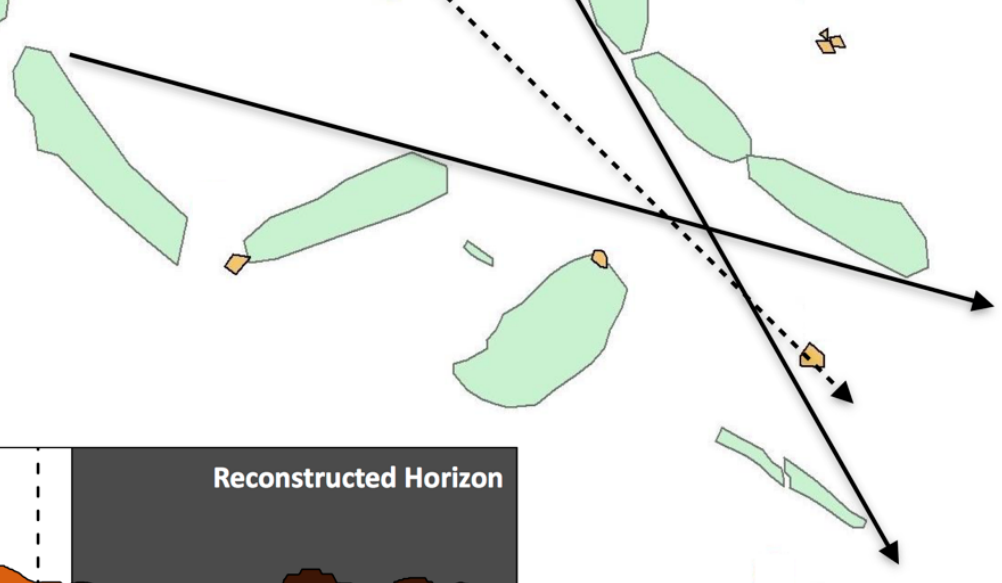

$\checkmark$

Figure 8 - The measured orientations of Dolmen I of Rego da Murta (arrows) and its reconstructed horizon (inset at bottom).

Looking now at the window of visibility (the solid arrows and non-shaded area of the reconstructed horizon of figure 8) reveals a view centred on a downwards slope, upon which the sun rose on December solstice (figure 9, top). Exactly on the same spot also rose Sirius, the brightest star in the night-sky, a possible alternative target. The view from this dolmen also encompasses one hilltop. The orientation to this hilltop might have been important for the megalith builders, as it also matches the orientation of stone pairs E-F and $\mathrm{G}-\mathrm{H}$ (table 2). This might have marked the position of moonrise on a minor standstill 
Accepted version of article published in Proceedings of Prehistoric Society 84 (2018): 207-224. DOI: 10.1017/ppr.2018.4

year (the other extreme of the 18.6 year cycle mentioned above), although here the coincidence of orography and moonrise is not as accurate as the previously mentioned one. At the same level of accuracy, this hill also marked the location where the three stars of Orion's belt (including Alnilam, the brightest of the three), recognizable even in the light-polluted skies of modern metropolises, rose in the Late Neolithic (figure 9, bottom).

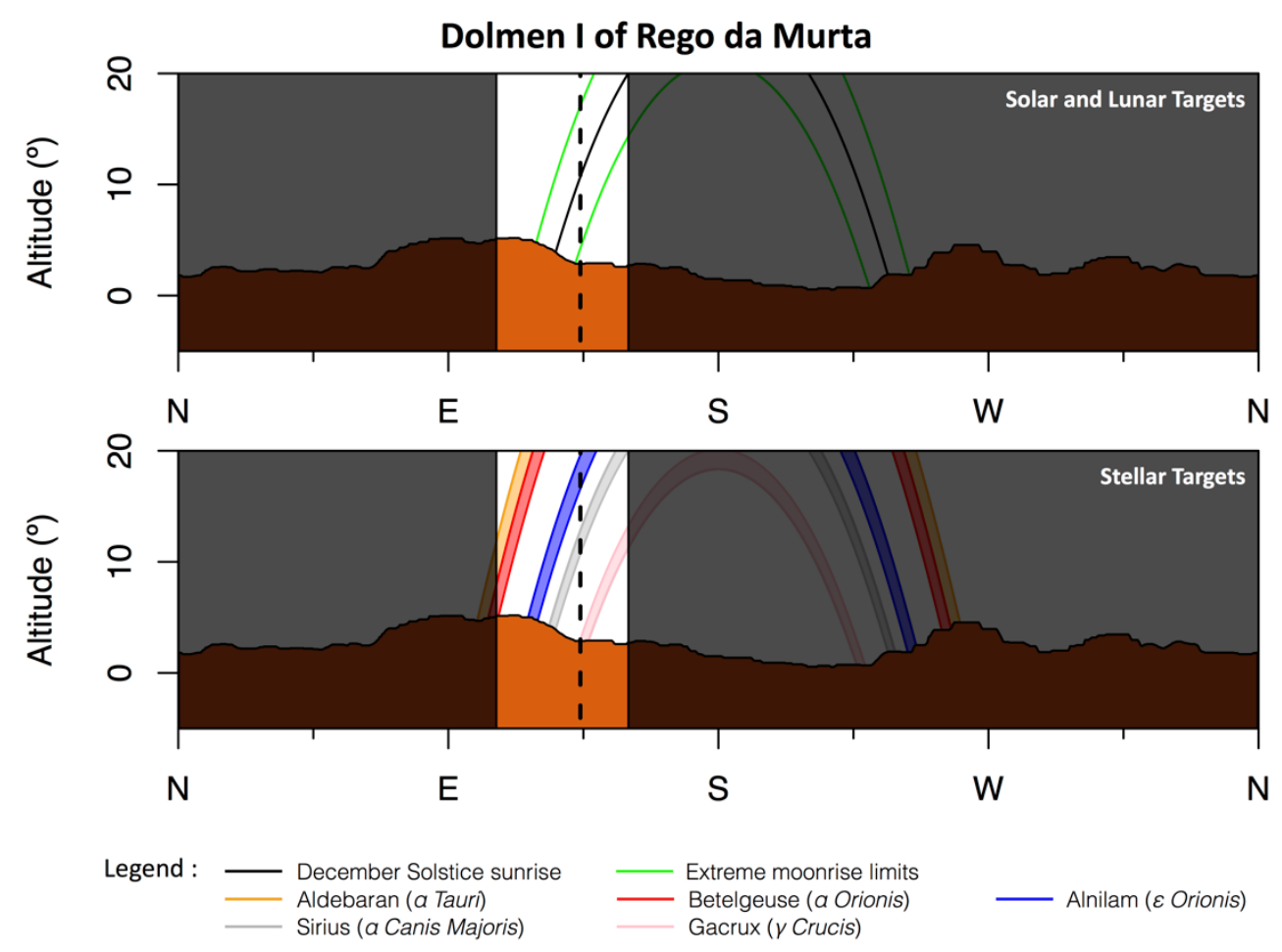

Figure 9 - Reconstructed horizon of Dolmen I of Rego da Murta with its window of visibility highlighted (area not grey-shaded) and traditional axis of symmetry (dashed vertical line). Also represented are the orbits of the sun on December solstice (top), the moon at its most extreme southern positions (top), and the five stars discussed in the main text (bottom).

\section{The orientation of Dolmen II}

Turning now our attention to Dolmen II, the traditionally-defined axis of symmetry is very different from that of Dolmen I: its declination is shifted $23^{\circ}$ northwards. However, because it is located 250 metres north of Dolmen I, it is still orientated towards the same hill on the horizon mentioned above (figure 10). The view from this dolmen is also narrower than that from Dolmen 1: it gives more prominence to the conspicuous hilltop already mentioned - the only orographic feature worthy of note in this megalithic cluster's eastern horizon. In effect, due to its northwards shift and the narrower window of visibility, the corridor of Dolmen 2 excludes most celestial events mentioned for Dolmen 1 (figure 11). 


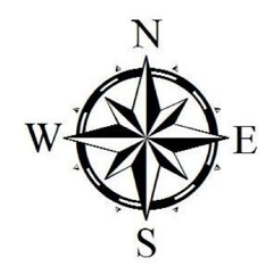

\section{Dolmen II de Rego da Murta (Alvaiázere, Portugal)}
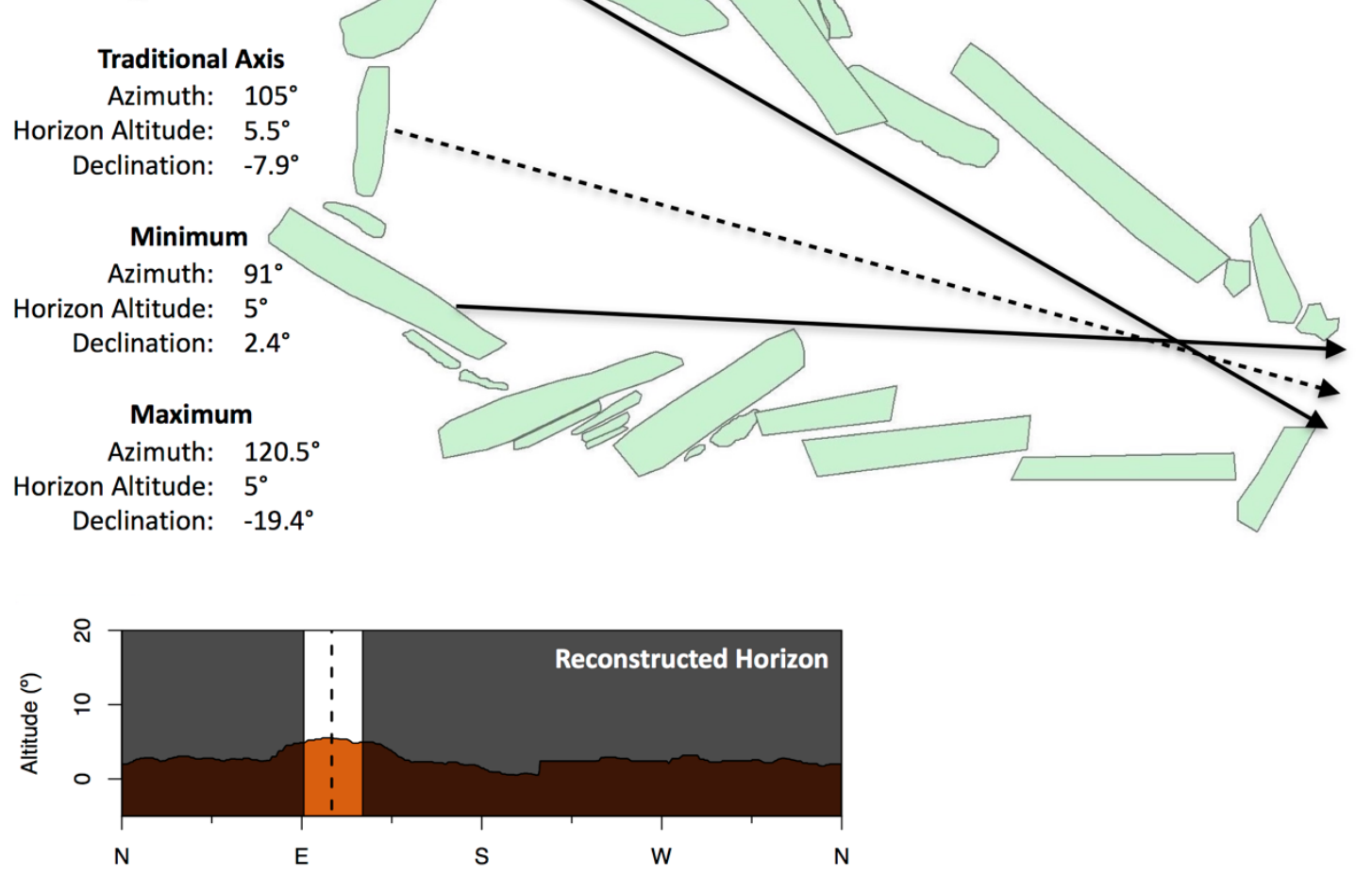

Figure 10 - The measured orientations of Dolmen II of Rego da Murta (arrows) and its reconstructed horizon (inset at bottom).

This orientation is harder to explain as targeting the sun or moon since it is far away from their most extreme rise positions (figure 11, top). However, this view would capture sunrise in the months immediately preceding the March equinox (i.e. late modern winter), and immediately succeeding the September Equinox (modern autumn). It would equally capture moonrise of two or three full moons just after the March Equinox, including the famous Spring Full Moon (da Silva 2004; Silva and Pimenta 2012), as well as two or three full moons just before the September Equinox.

The view, and indeed the traditional axis of symmetry, highlight the peak of the mentioned hilltop, whose declination is a very close match to the orientation highlighted by other megalithic clusters in both the North and the South of Portugal whose declinations are also in the $-8^{\circ}$ to $-10^{\circ}$ range (Silva 2013b; 2015). For the time period under consideration, this declination range matched that of the very bright red stars Aldebaran and Betelgeuse (figure 11, bottom), which have already been suggested as possible targets for those other clusters of dolmens in the country (Silva 2013a; 2013b; 2015). 
Accepted version of article published in Proceedings of Prehistoric Society 84 (2018): 207-224. DOI: 10.1017/ppr.2018.4
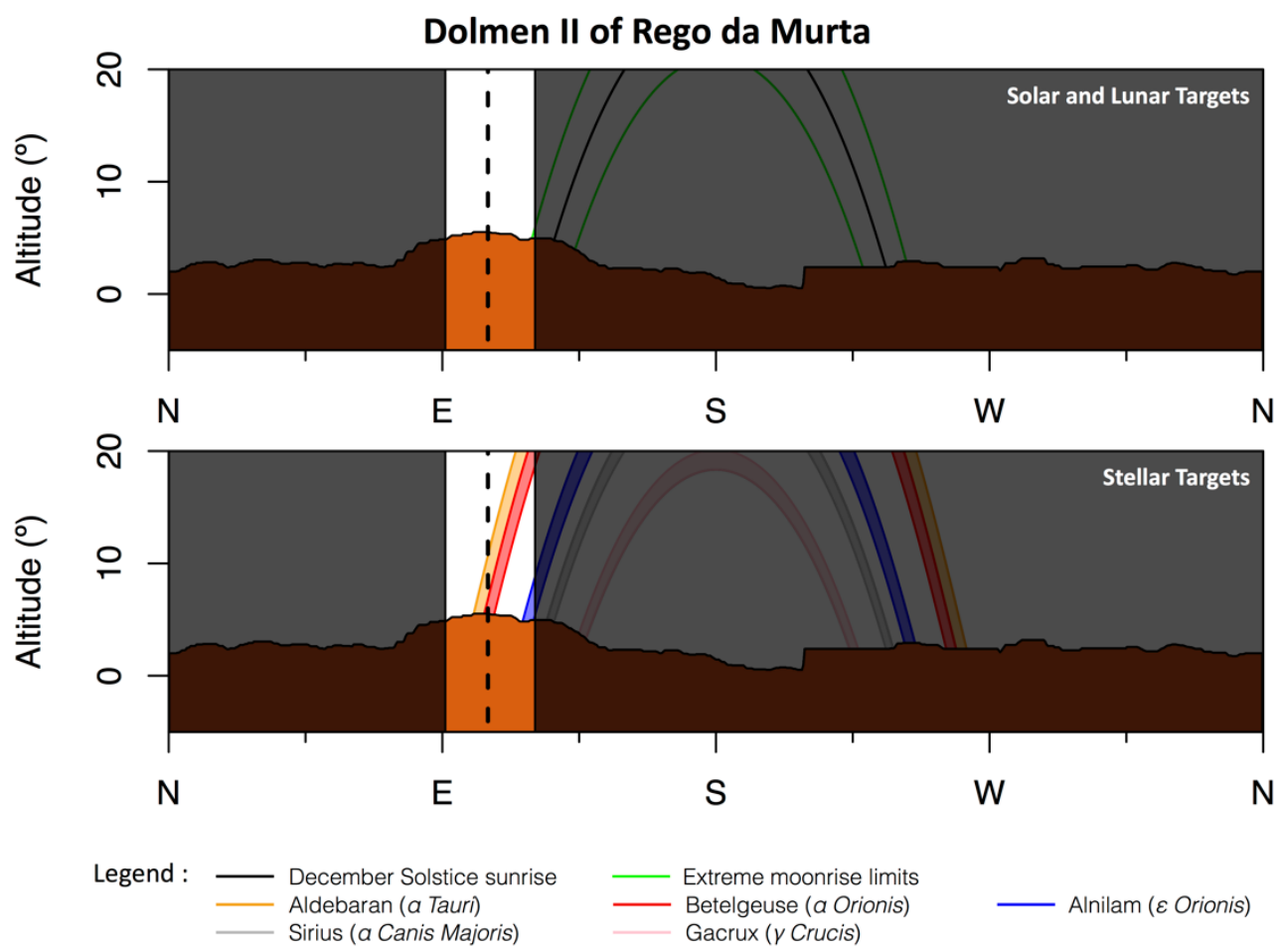

Figure 11 - Reconstructed horizon of Dolmen II of Rego da Murta with its window of visibility highlighted (area not grey-shaded) and traditional axis of symmetry (dashed vertical line). Also represented are the orbits of the sun on December solstice (top), the moon at its most extreme southern positions (top), and the five stars discussed in the main text (bottom).

\section{Interpretative Hypotheses}

The two dolmens of this cluster have orientations differing by about twenty degrees of declination and windows of visibility that exclude most commonalities between them, particularly in terms of the sky captured by their views. In addition to the null hypothesis that their orientation was arbitrary, one can formulate three potentially testable hypotheses to account for this significant difference.

The first hypothesis is that it is possible that the orientation of the two structures might be targeting the hilltop on the horizon and not any celestial object. The fact that both structures target the same hilltop, albeit different sections of it, does suggest that this was of significance to these Late Neolithic/Chalcolithic communities. This hypothesis could be strengthened by finds of other megalithic structures orientated towards this hill in its vicinity, as well as potential archaeological finds on the hilltop itself, which is a mere 2 $\mathrm{km}$ away from the cluster of Rego da Murta.

A second hypothesis is that, despite their different central axes, the two monuments target and align with a single celestial object, in addition to aligning with the same hill. This hypothesis is fleshed out by finding a pattern within the windows of visibility of the two dolmens, rather than thinking in terms of central axes, as advocated by Silva (2014). Comparing their ranges one finds that there is a small but considerable overlap both in azimuth $\left(106^{\circ}\right.$ to $\left.119^{\circ}\right)$ and declination $\left(-9^{\circ}\right.$ to $\left.-18.5^{\circ}\right)$. The stars Betelgeuse and those of Orion's belt are the only celestial objects of note that match this declination range for the period under consideration (compare figures 9 and 11, bottom).

The third hypothesis is that the two monuments were targeting different celestial objects. Dolmen I could be targeting sunrise in or around December solstice, full moon around 
Accepted version of article published in Proceedings of Prehistoric Society 84 (2018): 207-224. DOI: 10.1017/ppr.2018.4

June solstice, the star Sirius or the Southern Cross constellation. This is a rich part of the sky and, without any complementary and independent evidence it is impossible to choose one target over the others without making assumptions. On the other hand, Dolmen II could be targeting the Spring Full Moon, or the stars Aldebaran and Betelgeuse. This hypothesis could imply a transition in the cosmology of the dolmen builders but, considering that the currently available radiocarbon dates suggest contemporaneous primary deposition to both structures, a better interpretation might be that of complementarity. In this regard, it is interesting to consider whether this complementarity was also materialized in the different morphologies of the two structures, as well as in the way they were treated and internally modified in the periods following their erection.

When considering potential celestial targets, it is very important to consider their seasonality. Sun and moon do not rise and set in the same spot of the horizon throughout the year. Although stars always rise and set on the same spot, they cannot be seen to rise every night of the year. Hence when seasonality can be inferred from the archaeological record, it can help falsify or constrain the various archaeoastronomical hypotheses. Figure 12 graphically shows the seasons in which the targets mentioned thus far could be seen to rise in alignment with the two dolmens, rounded to the nearest fortnight. The sun and Gacrux only act as visible targets in the colder half of the year, whereas all the other targets put the emphasis on the warmer half, especially the summer, with the Spring Full Moon and Aldebaran being the only spring targets visible from Dolmen II.

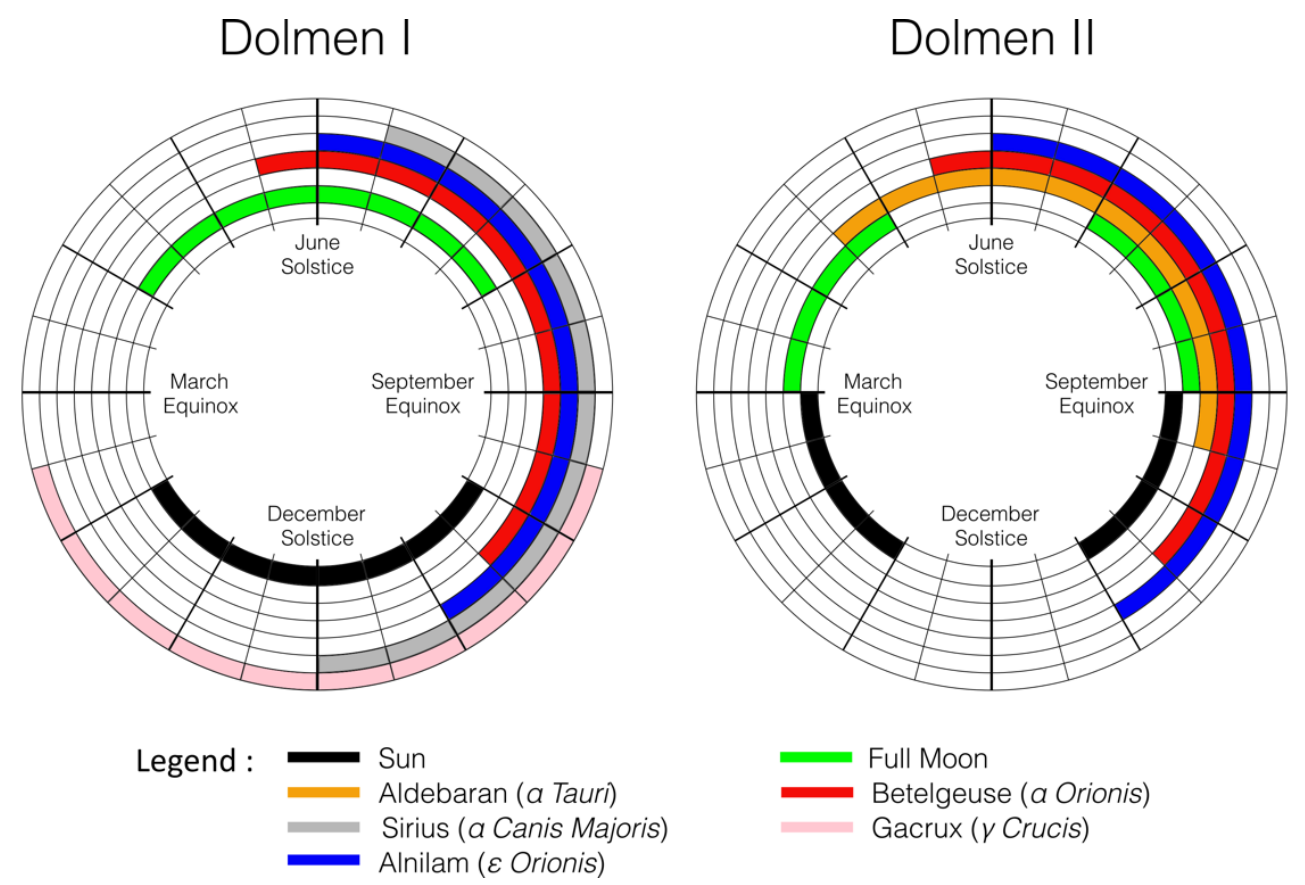

Figure 12 - Seasonality of observable celestial rises from within the chamber of the two dolmens. Coloured regions indicate the corresponding celestial object can be seen as it is rising.

A better understanding of the seasonality of occupation and use of the megalithic cluster could help discern between the potential celestial targets and exclude several, if not most of them. It could also help discern between the above-mentioned hypotheses, since only two of the targets considered (Betelgeuse and Alnilam, the later of Orion's belt) overlap between the two structures. Unfortunately, the seasonality of occupation of the cluster, as inferred from the archaeological record, is inconclusive. Access to the dolmens would 
Accepted version of article published in Proceedings of Prehistoric Society 84 (2018): 207-224. DOI: 10.1017/ppr.2018.4

have been difficult in winter as they are located on floodplains. However, based on the presently-available data, or lack thereof, we refrain from attempting to speculate any further, but hope to return to them later when more evidence is available.

\section{Conclusion}

We have remarked on the finding of several small quartzite stones on Dolmen I of Rego da Murta, embedded in the deepest layers and predating the erection of the megalithic monument. Their location relative to the dolmen's orthostats, the distances between them that mirror key lengths of the megalithic structure and their orientations are indicative of their use with respect to the planning of the orientation and construction of the monument (Figueiredo 2006, 170). This being the case, this is a rare West Iberian example demonstrating a sense of planning, forethought and coordination, as well as some standardization of measurement and the possible erection of preliminary structures to aid in the orientation and construction of the megalithic monuments themselves.

We have also measured and analysed the orientation of the two dolmens of the Rego da Murta cluster. Their orientations focus around a particular hilltop on the horizon, which may betray intention on the part of their builders. However, their morphological differences are also reflected in their orientations, which differ by about twenty degrees, excluding most commonalities in potential celestial alignments. We consider and discuss possible celestial targets, including Sun, Moon and stars, the most prominent of which are Aldebaran and those of the modern constellation of Orion (figure 13). These have already been suggested as celestial targets, and seasonal markers, for the megalithbuilding communities of the Mondego valley, to the north-east of Rego da Murta (e.g. Silva 2015).

Other possibilities include Full Moonrise in the warmer half of the year, or sunrise in the coldest. So as to better constrain the, and indeed exclude most, potential targets, we argue that an improved understanding of the seasonality of use and occupation of the Rego da Murta cluster is essential. We hope that future excavations of the remaining structures might provide further clues.

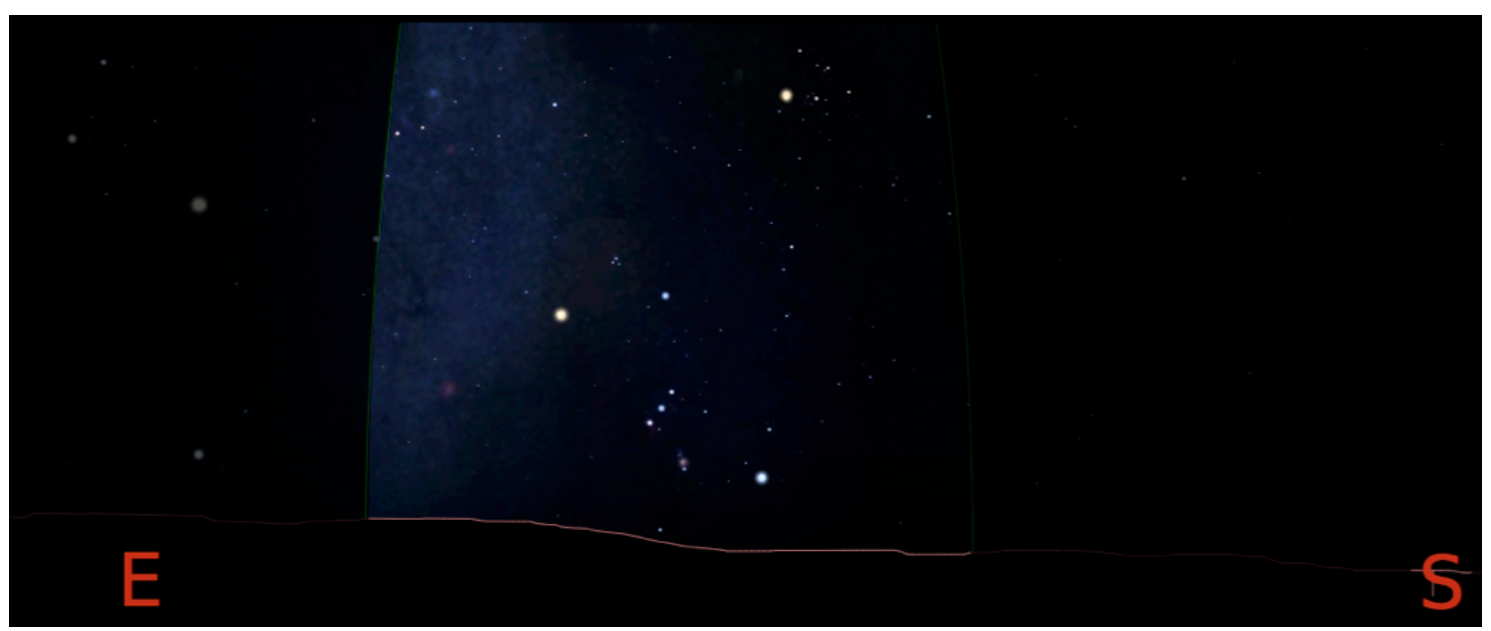

Figure 13 - Orion rising as seen from within the chamber of Dolmen I of Rego da Murta, blacking out the parts of the sky not visible. Betelgeuse is the red star on the top-left of Orion. Aldebaran, another bright red star is also visible on the top right. Reconstruction done using Stellarium v0.15.1 (http://www.stellarium.org). 
Accepted version of article published in Proceedings of Prehistoric Society 84 (2018): 207-224. DOI: 10.1017/ppr.2018.4

\section{Acknowledgements}

FS has received funding from the European Union (EU)'s Horizon 2020 research and innovation programme under the Marie Skłodowska-Curie Individual Fellowships / H2020-MSCA-IF-2014 Grant Agreement n. 656264.

\section{Bibliography}

Baptista, A. 2006. Vestígios Arqueológicos, Rio de Moinhos II. Riomoinhense 9, 4-5

Batista, A. 2013. Sinais da importância da pedra na evolução humana na região de Abrantes. In P. Passos (ed.) Em pedra: lascar, polir, esculpir, 8-33. Abrantes: Câmara Municipal de Abrantes

Chakraborty, A., Feigelson, E. \& Babu, G. 2014. astrolabe: Astronomy Users Library for R. URL: http://CRAN.R-project.org/package=astrolibR

Crucifix, M. 2016. palinsol: Insolation for Palaeoclimate Studies. URL: https://CRAN.Rproject.org/package=palinsol

Cruz, A.R. 2004. Monumento 5 da Jogada - Campanha Arqueológica 2003. Techne 9, 89-114

Cruz, A.R., Berruti, G.L.F., Delfino, D. \& Gaspar, F. 2016. The lithic hoard of hypogeum of Colos (Abrantes, Middle Tagus valley-Portugal): Shadows of Rituals. Mediterranean Archaeology and Archaeometry 16(1), 75-86

Cruz, D. 1995. Cronologia dos monumentos com tumulus do Noroeste peninsular e da Beira Alta. Estudos Pré-Históricos 3, 81-120

da Silva, C.M. 2004. The spring full moon. Journal for the History of Astronomy 35, 475-478

Figueiredo, A. 2004a. A Anta I do Rego da Murta. Descrição sumária dos trabalhos efetuados em 2003. Techne 9, 115-126

Figueiredo, A. 2004b. A Anta II de Rego da Murta (Alvaiázere) - Resultados da 1a campanha de escavações. Techne 9, 127-138

Figueiredo, A. 2005. Contributo para a análise do megalitismo no Alto Ribatejo: O Complexo Megalítico de Rego da Murta, Alvaiázere. Al-madan 13, 134-136

Figueiredo, A. 2006. Complexo Megalítico de Rego da Murta. Pré-história recente do Alto Ribatejo (IV-IIo milénio a.C.): Problemáticas e Interrogações. Unpublished PhD thesis, Universidade do Porto

Figueiredo, A. 2007. Walking in a Way: Some Conclusions of the Recent Pre-History in Alto Ribatejo Region. In A. Figueiredo \& G. Leite Velho (eds) The world is in your eyes. CAA2005. Computer Applications and Quantitative Methods in Archaeology. Proceedings of the 33rd Conference, Tomar, March 2005, 353-358. Tomar: CAA Portugal

Figueiredo, A. 2010. Rituals and Death cults in recent Prehistory in central Portugal (Alto Ribatejo). Documenta Praehistorica XXXVII, 85-94. Available online: http://revije.ff.unilj.si/DocumentaPraehistorica/article/view/37.8/1699

Figueiredo, A. 2013a. O Sítio Arqueológico da Anta I de Rego da Murta. Antrope 0, 9-17. Available online:

http://www.cph.ipt.pt/download/AntropeDownload/ANTROPE\%200/revista antrope N0.pdf 
Accepted version of article published in Proceedings of Prehistoric Society 84 (2018): 207-224. DOI: 10.1017/ppr.2018.4

Figueiredo, A. 2013b. Os menires do Complexo Megalítico de Rego da Murta (Alvaiázere, Leiria): resultados das intervenções do Menir I e II de Rego da Murta. Antrope 0, 213-225. Available onine:

http://www.cph.ipt.pt/download/AntropeDownload/ANTROPE\%200/revista antrope N0.pdf

Hoskin, M. 2001. Tombs temples and their orientations. Bognor Regis: Ocarina Books.

Kosowsky, M. 2016. HeyWhatsThat. Electronic source: http://www.heywhatsthat.com/ Accessed 18/01/2016

Malville, J.M. 2015. Chimney Rock and the Ontology of Skyscapes: How Astronomy, Trade, and Pilgrimage Transformed Chimney Rock. Journal of Skyscape Archaeology 1(1), 39-64

R Core Team. 2016. R: A language and environment for statistical computing. R Foundation for Statistical Computing, Vienna, Austria. URL: https://www.R-project.org/

Reimer, P.J., Bard, E., Bayliss, A., Beck, J.W., Blackwell, P.G., Bronk Ramsey, C., Buck, C.E., Chenge, H., Edwards, R.L, Friedrich, M., Grootes, P.M., Guilderson, T.P., Haflidason, H., Hajdas, I., Hatté, C., Heaton, T.J., Hoffmann, D.L., Hogg, A.G., Hughen, K.A., Kaiser, K.F., Kromer, B., Manning, S.W., Niu, M., Reimer, R.W., Richards, D.A., Scott, E.M., Southon, J.R., Staff, R.A., Turney, C.S.M. \& van der Plicht, J. 2013. Intcal 13 and marine13 radiocarbon age calibration curves $0-50,000$ years cal BP. Radiocarbon $55,1869-87$

Rocha, L. 2010. As origens do megalitismo funerário alentejano: revisitando Manuel Heleno. Promontoria $7 / 8,45-98$

Ruggles, C.L.N. 1999. Astronomy in Prehistoric Britain and Ireland. Yale University Press, New Haven and London

Silva, F. 2013a. Landscape and Astronomy in Megalithic Portugal: the Carregal do Sal Nucleus and Star Mountain Range. Papers from the Institute of Archaeology 22, 99-114

Silva, F. 2013b. Astronomia e Paisagem no Megalistismo do Norte do Pais: Problemas e perspectivas. In Arqueologia em Portugal - 150 anos, 427-433. Lisbon: AAP

Silva, F. 2014. A Tomb with a View: New Methods for Bridging the Gap between Land and Sky in Megalithic Archaeology. Advances in Archaeological Practice: A journal of the society for American Archaeology 2(1), 24-37

Silva, F. 2015. The view from within: a "Time-Space-Action" approach to Megalithism in Central Portugal. In F. Silva \& N. Campion (eds) Skyscapes: The Role and Importance of the Sky in Archaeology, 120-139. Oxford: Oxbow Books

Silva, F. \& Pimenta, F. 2012. The crossover of the sun and the moon. Journal for the History of Astronomy 43(2), 191-208

Sims, L. 2016. What is the Minor Standstill of the Moon? Journal of Skyscape Archaeology 2(1), 67-76

Thom, A. 1962. The Megalithic Unit of Length. Journal of the Royal Statistical Society. Series A $125,243-251$

Waterman, A., Figueiredo, A., Thomas, J.T. \& Peate, D.W. 2013. Identifying migrants in the late neolithic burials of the antas of rego da murta (alvaiázere, portugal) using strontium isotopes. Antrope 0, 190-197. Available online: http://www.cph.ipt.pt/download/AntropeDownload/ANTROPE\%200/revista antrope N0.pdf

Velho, A.F. 2003. A Anta I do Rego da Murta - Campanha de 2001. Thechne 8, 23-28

Velho, A.F. 2006. Contributo para o estudo e compreensão do megalitismo no Alto Ribatejo: A Anta I de Rego da Murta, Leiria. In N. Bicho \& A.F. Carvalho (eds) Simbolismo, Arte e Espaços 
Accepted version of article published in Proceedings of Prehistoric Society 84 (2018): 207-224. DOI: 10.1017/ppr.2018.4

Sagrados na Pré-História da Península Ibérica: Atas do IV Congresso de Arqueologia Peninsular (Faro, 14 a 19 de Setembro de 2004), 69-88. Faro : Universidade do Algarve, Centro de Estudos de Património 